\title{
Morphometric analysis of Littoraria angulifera (Caenogastropoda) in estuarine regions of northeastern Brazil
}

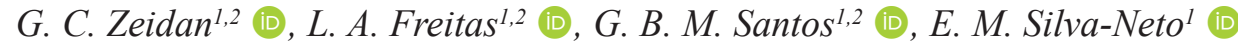 \\ and $G$. Boehs ${ }^{1,2 *}$ \\ 'Laboratório de Moluscos Marinhos - LMM, Universidade Estadual de Santa Cruz - UESC, Rodovia Ilhéus-Itabuna, Km \\ 16, CEP 45662-900, Ilhéus, BA, Brasil \\ ${ }^{2}$ Programa de Pós-graduação em Ciência Animal, Universidade Estadual de Santa Cruz - UESC, Rodovia Ilhéus-Itabuna, \\ Km 16, CEP 45662-900, Ilhéus, BA, Brasil \\ *e-mail: gboehs@uesc.br
}

Received: September 17, 2018 - Accepted: November 1, 2018 - Distributed: May 31, 2020

(With 3 figures)

\begin{abstract}
The gastropod Littoraria angulifera (Littorinidae) is an exclusively estuarine mollusk with Neotropical anfiatlantic distribution. Recent studies indicate a possible use of the species as bioindicator. The aim of this study was to analyze the shell height, as well as to perform a morphometric analysis of the reproductive apparatus of $L$. angulifera collected in 22 sampling points located between latitudes 13 ${ }^{\circ} 54^{\prime} \mathrm{S}$ and 15 $5^{\circ} 44^{\prime} \mathrm{S}$ in the South Atlantic, State of Bahia, Northeastern Brazil. The specimens were obtained in different estuarine environments including mangroves, as well as on rocks and concrete walls in places close to ports, shipyards and berths during January and February 2014. All specimens $(\mathrm{n}=880)$ were analyzed regarding the sex and shell height/morphology, 440 were analyzed about the reproductive apparatus morphometry and 15 in histological description. The average shell height of animals from artificial substrates in nautical areas was lower $(p<0.05)$ than the animals from mangroves, mainly in preserved areas, evidencing relation with human impacts and desiccation. The morphometric analysis of $L$. angulifera reproductive tract allowed us to conclude that the length of prostate in males and of palial oviduct in females may be useful in the reproductive evaluation of the species.
\end{abstract}

Keywords: estuaries, gastropods, human impacts, morphology.

\section{Análise morfométrica de Littoraria angulifera (Caenogastropoda) em regiões estuarinas do Nordeste do Brasil}

\begin{abstract}
Resumo
O gastrópode Littoraria angulifera (Littorinidae) é um molusco exclusivamente estuarino com distribuição anfiatlântica neotropical. Estudos recentes indicam um possível uso dessa espécie como bioindicadora. No presente estudo teve-se por objetivos analisar a altura da concha, assim como realizar uma análise morfométrica do aparato reprodutor

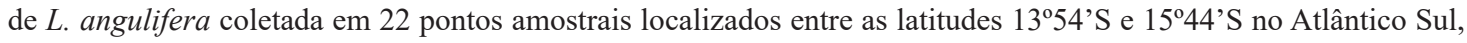
Estado da Bahia, Nordeste do Brasil. Os exemplares foram obtidos em diferentes ambientes estuarinos, incluindo manguezais, assim como sobre rochas e paredes de concreto em lugares próximos a portos, estaleiros e atracadouros, durante janeiro e fevereiro de 2014. Todos os espécimes $(\mathrm{n}=880)$ foram analisados quanto à morfologia/ altura da concha e sexo, 440 quanto à morfometria do aparelho reprodutor e 15 em descrição histológica. A média de altura da concha de animais de substratos artificiais em áreas náuticas foi menor $(\mathrm{p}<0,05)$ do que de animais de manguezais, principalmente de áreas preservadas, evidenciando relação com o impacto antrópico e a dessecação. A análise morfométrica do trato reprodutivo de L. angulifera levou à conclusão que o comprimento da próstata em machos e do oviduto palial em fềmeas pode ser útil na avaliação reprodutiva da espécie.
\end{abstract}

Palavras-chave: estuários, gastrópodes, impactos antrópicos, morfologia.

\section{Introduction}

Estuaries and mangroves feature a variety of ecological niches that provide a diverse fauna with representatives of various phyla, some living temporarily and others passing their entire life cycle in these places (Macnae, 1969).
Among these, a small group of organisms (consisting of representatives of annelids, crustaceans and mollusks) has a mandatory association with the estuarine environments (Plaziat, 1984). This group includes mesogastropods of 
the family Littorinidae (Caenogastropoda), like species of the genus Littoraria Gray, 1833, that adapted to live in these environments (Reid, 1986; Merkt and Ellison, 1998). Because they often present morphological responses to the specific environment they occupy, as well as to human impacts, these mollusks are becoming attractive for use in environmental monitoring (Tanaka and Maia, 2006; Melo et al., 2012; Costa et al., 2013; Martínez et al., 2013). Although mesogastropods are considered less sensitive than neogastropods to some types of chemical contamination (Bauer et al., 1995), these are interesting alternatives to places where there are no neogastropods, as is the case of mangroves.

Littoraria angulifera (Lamarck, 1822), the southern periwinkle, lives in Neotropical mangroves/estuaries and has anfiatlantic occurrence (Kohlmeyer and Bebout, 1986; Reid et al., 1986; Merkt and Ellison, 1998). On the Brazilian coast, L. angulifera occurs from the State of Ceará to the State of Santa Catarina, including in oceanic islands, being very abundant in the northeast region (Reid, 1989; Matthews-Cascon and Lotufo, 2006). Recruits live in the shade of leaves and small twigs in the mesolitoral close to the water level and as they grow and increase their production of mucus, reach higher portions in mangrove trunks and roots (Vermeij, 1973; Kohlmeyer and Bebout, 1986). The species is an ovoviviparous organism (Reid, 1989) and presents detritivorous/microphagic habit (Gutierrez, 1988), feeding mainly on lichens and fungi (Kohlmeyer and Bebout, 1986).

The coast of the state of Bahia presents about $1,100 \mathrm{~km}$ of extension, in which are located several estuaries. The mangroves of this part of the Brazilian coast are well developed, with trees that reach up to $15 \mathrm{~m}$ in height in certain stretches (Schaeffer-Novelli et al., 1990). Despite the intense urbanization along this coast, some areas are still relatively well preserved, and extensive stretches are legally protected as conservation units. For example, on the southern coast of Bahia, were established a few years ago the Federal Marine Extractive Reserve (RESEX) of Canavieiras and the Environmental Preservation Area of Camamu (APA of Camamu), a conservation area of municipal and state jurisdiction. Artisanal fishing, nautical tourism and crustaceans/ mollusks extrativism are the main socioeconomic activities of traditional populations of this region.

In general, environmental damage on the coast of Bahia is mainly associated with the disorderly rural and urban occupation in the surroundings of rivers and estuaries, which also often receive untreated domestic sewage, as well as pesticide residues from upstream crops (Schiavetti et al., 2002). Also, because it is an area with intense naval activity, as well as nautical tourism and artisanal fishing, several impacts are also due to maritime activities. One of these impacts is the organotin contamination that can cause sexual alterations and reproductive unfeasibility in marine gastropods, as verified in the region by Zeidan and Boehs (2017) in the neogastropod Stramonita rustica (Lamarck, 1822).

Within the assumptions for bioindication referred by Mccarty and Munkittrick (1996), L. angulifera meets several selection criteria for estuaries and mangroves monitoring, among them, easy collection and manipulation and its conspicuous presence in these systems. Nevertheless, few studies have used it as a sentinel species of environmental quality in mangroves/ estuaries (Martínez et al., 2013). Recent studies in Southeast (Costa et al., 2013) and Northeast Brazilian coast (Zeidan et al., 2018), suggest the feasibility of using L. angulifera as bioindicator for organotin contamination that still been used in antifouling paints of boats.

The objective of this study was to analyze the height of the shell, and to perform a morphometric analysis of the reproductive apparatus of L. angulifera in the South Atlantic, State of Bahia, Brazil.

\section{Material and Methods}

\subsection{Samples}

The samples $(n=880)$ were obtained by active search/ manual capture, during January and February of 2014, summer in the South Atlantic, in 22 sampling stations (St) located between latitudes $13^{\circ} 54^{\prime} \mathrm{S}$ and $15^{\circ} 44^{\prime}$ S (Table 1), covering, from the south to the north, the municipalities of Belmonte, Canavieiras, Ilhéus, Itacaré, Maraú and Camamu, in a stretch of approximately $300 \mathrm{~km}$ of coastal extension. A total of 40 specimens / station were collected during low tide of syzygy, using the tide chart of the Brazilian Navy (Brasil, 2014) as a reference.

The specimens were sampled in the meso and supralittoral on mangroves (some more conserved with ample vegetal cover and more restrict access for human and for that reason less impacted and other ones with easier access, where vegetal coverage is more sparse and visibly anthropized), as well as on rocks and concrete walls in places close to ports, shipyards and berths. The specimens were placed in plastic bags labeled and transported to the State University of Santa Cruz - UESC (Ilhéus) for laboratory procedures. The samplings were authorized by the Chico Mendes Institute for Biodiversity Conservation - ICMBio, Brazil, through the license number 20912-3 / 2014.

\subsection{Laboratory processing}

The processing was done at the Laboratory of Marine Mollusks (LMM / UESC, Ilhéus, Brazil) and complemented at the Laboratory of Estuarine Marine Ecology (LEME, University of Aveiro, Portugal). After the macroscopic shell analysis of color and texture, the specimens were measured in relation to the main axis (height), using a digital caliper with $0.01 \mathrm{~mm}$ precision and anesthetized with $10 \%$ Magnesium Chloride $\left(\mathrm{MgCl}_{2}\right)$ in distilled water for 1 hour, following the recommendation of Zeidan et al. (2018). The shell was broken with a table vise for sex observation and analyzes of the reproductive tract. For this last analysis were randomly selected 20 individuals / sampling station with height $\geq 10 \mathrm{~mm}$. A stereomicroscope (Leica) at 10x, 40x and 100x magnifications was used for anatomical observations.

Taking as reference the anatomical and ecological descriptions made by Marcus and Marcus (1963), Merkt and Ellison (1998) and Reid (1999), were analyzed in both sexes the color/ texture of the gonad, as well as of the gonoducts and other reproductive organs. To analyze the genital morphometry were measured in males the length of the penis and of the prostate and the distance from the 
prostate opening to the anus. In females were measured the length of the palial oviduct and the distance between the anus and the aperture of the vulva.

Fragments of reproductive tract apparatus of 15 specimens (randomly selected from the pool of 880 samples), including males and females, were cut with a scalpel and subjected to histological analysis, with fixation in Bouin solution for 24 hours, preservation in $70 \%$ ethanol, followed by alcoholic dehydration, diaphanization with Histo-Clear ${ }^{\circledR}$ and embedding in paraffin. The tissues were cut into a microtome with a thickness of 5-7 $\mu \mathrm{m}$, stained with Harris hematoxylin and eosin (H \& E) and mounted on DPX resin. The material was analyzed under a light microscope, in total magnifications of $100 \mathrm{x}$ and $400 \mathrm{x}$. The slides were deposited in the LMM / UESC histological collection.

\subsection{Statistical analyzes}

Analyzes of variance (ANOVA), complemented with the Tukey a posteriori test were used to compare the height of the shell among sample stations and between sexes. Pearson and Spearman correlation analyzes, according to the normality of the data, were used to interpret the morphometric relationships of shell height and lengths / distances of reproductive organs. The confidence level used was 95\%. Analyzes were performed using SigmaStat software.

\section{Results}

\subsection{Shell morphology}

The external morphology of the shell presented typical turbinate shape, with fine texture, but robust and with a sharp vertex. Color polymorphism was observed, including beige, brown, yellow-orange and purple, with dark brown predominating (Figure 1). In the sample stations St3, St6,
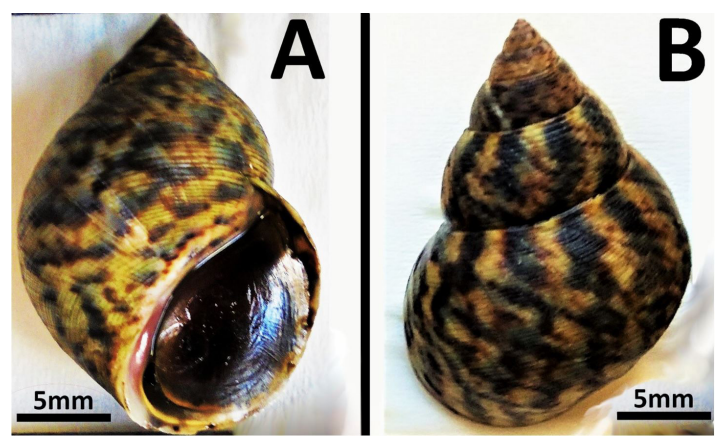

Figure 1. Example of Littoraria angulifera from the coast of the state of Bahia, northeastern Brazil, seen with the naked eye. A: ventral view of the shell and B: dorsal view.

Table 1. Results of shell height (mm), number of males and females and sex ratio of Littoraria angulifera in 22 sampling stations on the southern coast of Bahia, northeast Brazil.

\begin{tabular}{|c|c|c|c|c|c|}
\hline $\begin{array}{l}\text { Sample } \\
\text { stations }\end{array}$ & Geographical coordinates & $\begin{array}{l}\text { County/type of } \\
\text { environment }\end{array}$ & $\begin{array}{c}\text { Number of } \\
\text { males/females } \\
\text { and sex ratio }()\end{array}$ & $\begin{array}{c}\text { Shell heigth } \\
\text { (Mean } \pm \text { SD) } \\
\text { Males }\end{array}$ & $\begin{array}{c}\text { Shell heigth } \\
\text { (Mean } \pm \text { SD) } \\
\text { Females }\end{array}$ \\
\hline St1 & $15^{\circ} 41^{\prime} 40.17^{\prime \prime} \mathrm{S} / 38^{\circ} 56^{\prime} 46.45^{\prime \prime} \mathrm{W}$ & Belmonte* & $27 / 13(2.07)$ & $19.47 \pm 3.25$ & $22.22 \pm 2.76$ \\
\hline St2 & $15^{\circ} 43^{\prime} 7.83^{\prime \prime} \mathrm{S} / 38^{\circ} 55^{\prime} 30.82^{\prime \prime} \mathrm{W}$ & Belmonte* & $25 / 15(1.67)$ & $22.25 \pm 2.42$ & $23.89 \pm 2.28$ \\
\hline $\mathrm{St} 3$ & $15^{\circ} 43^{\prime} 8.30^{\prime \prime} \mathrm{S} / 38^{\circ} 55^{\prime} 3.14^{\prime \prime} \mathrm{W}$ & Canavieiras* & $25 / 15(1.67)$ & $22.94 \pm 1.85$ & $23.76 \pm 2.12$ \\
\hline St4 & $15^{\circ} 44^{\prime} 3.59^{\prime \prime} \mathrm{S} / 38^{\circ} 55^{\prime} 1.67^{\prime \prime} \mathrm{W}$ & Canavieiras* & $15 / 25(0.6)$ & $23.90 \pm 1.97$ & $23.77 \pm 3.08$ \\
\hline St5 & $15^{\circ} 44^{\prime} 7.95^{\prime \prime} \mathrm{S} / 38^{\circ} 55^{\prime} 9.49^{\prime \prime} \mathrm{W}$ & Canavieiras* & $22 / 18(1.22)$ & $23.90 \pm 1.50$ & $24.78 \pm 2.38$ \\
\hline St6 & $15^{\circ} 41^{\prime} 0.07^{\prime \prime} \mathrm{S} / 38^{\circ} 56^{\prime} 38.06^{\prime \prime} \mathrm{W}$ & Canavieiras $* *$ & $23 / 17(1.35)$ & $14.09 \pm 2.42$ & $13.72 \pm 2.99$ \\
\hline St7 & $15^{\circ} 44^{\prime} 7.13^{\prime \prime} \mathrm{S} / 38^{\circ} 57^{\prime} 3.54^{\prime \prime} \mathrm{W}$ & Canavieiras* & $24 / 16(1.5)$ & $21.72 \pm 2.72$ & $21.20 \pm 2.89$ \\
\hline St8 & $15^{\circ} 39^{\prime} 34.54^{\prime \prime} \mathrm{S} / 38^{\circ} 56^{\prime} 33.88^{\prime \prime} \mathrm{W}$ & Canavieiras* & $22 / 11(2.63)$ & $25.00 \pm 1.95$ & $25.08 \pm 2.05$ \\
\hline St9 & $15^{\circ} 38^{\prime} 29.87^{\prime \prime} \mathrm{S} / 38^{\circ} 56^{\prime} 50.02^{\prime \prime} \mathrm{W}$ & Canavieiras* & $19 / 23(0.82)$ & $22.67 \pm 1.98$ & $21.89 \pm 2.66$ \\
\hline St10 & $15^{\circ} 36^{\prime} 0.97^{\prime \prime} \mathrm{S} / 38^{\circ} 56^{\prime} 56.68^{\prime \prime} \mathrm{W}$ & Canavieiras* & $24 / 16(1.5)$ & $21.27 \pm 3.32$ & $22.73 \pm 1.93$ \\
\hline St11 & 1448’34.48”S/39²'21.76”W & Ilhéus* & $28 / 12(3.5)$ & $22.38 \pm 2.50$ & $22.11 \pm 2.28$ \\
\hline St12 & $14^{\circ} 48^{\prime} 10.17^{\prime \prime S} / 39^{\circ} 2^{\prime} 21.32^{\prime \prime} \mathrm{W}$ & Ilhéus* & $22 / 18(1.22)$ & $21.91 \pm 1.79$ & $19.78 \pm 2.19$ \\
\hline St13 & $14^{\circ} 46^{\prime} 56.93 ” \mathrm{~S} / 39^{\circ} 1{ }^{\prime} 59.89^{\prime \prime} \mathrm{W}$ & Ilhéus*** & $18 / 22(0.81)$ & $15.49 \pm 2.37$ & $15.02 \pm 2.17$ \\
\hline St14 & $14^{\circ} 16^{\prime} 38.65^{\prime \prime} \mathrm{S} / 38^{\circ} 59^{\prime} 30.98^{\prime \prime} \mathrm{W}$ & Itacaré* & $18 / 22(1.12)$ & $21,40 \pm 3.85$ & $20.45 \pm 3.45$ \\
\hline St15 & $13^{\circ} 55^{\prime} 2.60^{\prime \prime} \mathrm{S} / 39^{\circ} 0 \prime 5.90^{\prime \prime} \mathrm{W}$ & Camamu* & $20 / 20(1.0)$ & $23.10 \pm 2.55$ & $22.24 \pm 3.02$ \\
\hline St16 & $13^{\circ} 54^{\prime} 51.79^{\prime \prime} \mathrm{S} / 39^{\circ} 1^{\prime} 8.78^{\prime \prime} \mathrm{W}$ & Camamu* & $24 / 16(1.5)$ & $23.10 \pm 6.19$ & $24.21 \pm 2.42$ \\
\hline St17 & $13^{\circ} 57^{\prime} 33.76^{\prime \prime} \mathrm{S} / 39^{\circ} 1^{\prime} 54.49^{\prime \prime} \mathrm{W}$ & Camamu* & $15 / 25(0.6)$ & $22.75 \pm 1.84$ & $23.71 \pm 3.05$ \\
\hline St18 & $13^{\circ} 59^{\prime} 33.85^{\prime \prime} \mathrm{S} / 39^{\circ} 0 ’ 3.77^{\prime \prime} \mathrm{W}$ & Camamu* & $22 / 18(1.22)$ & $23.05 \pm 4.74$ & $23.05 \pm 4.74$ \\
\hline St19 & $13^{\circ} 58^{\prime} 43.12^{\prime \prime} \mathrm{S} / 39^{\circ} 5^{\prime} 3.80^{\prime \prime} \mathrm{W}$ & Maraú* & $23 / 17(1.35)$ & $25.00 \pm 2.78$ & $25.00 \pm 2.56$ \\
\hline St20 & $14^{\circ}$ 1'32.89”S/38'59'22.06”'W & Maraú** & $18 / 22(0.81)$ & $17.63 \pm 1.94$ & $17.63 \pm 1.82$ \\
\hline St21 & $14^{\circ} 47^{\prime} 3.15^{\prime \prime} \mathrm{S} / 39^{\circ} 2^{\prime} 13.14^{\prime \prime} \mathrm{W}$ & Ilhéus*** & $12 / 28(0.42)$ & $13.74 \pm 1.41$ & $14.51 \pm 1.09$ \\
\hline $\mathrm{St} 22$ & $14^{\circ} 34^{\prime} 26.25^{\prime \prime} \mathrm{S} / 39^{\circ} 3^{\prime} 8.20^{\prime \prime} \mathrm{W}$ & Ilhéus* & $31 / 9(3.44)$ & $26.62 \pm 2.35$ & $26.62 \pm 2.67$ \\
\hline
\end{tabular}

Type of environment: * mangrove; ** concrete walls of berths; $* * *$ concrete walls of port region. $\mathrm{n}=880$. 
St20 and St21 (Table 1), the shells were lighter and had less physical resistance to breaking. No evidence of shell sexual dimorphism was observed.

\subsection{Shell height and sex ratio}

Considering all the animals collected $(n=880)$, the height of the shell ranged from 5.36 to $29.51 \mathrm{~mm}$, with a mean of $20.94 \mathrm{~mm}$, Standard Deviation (SD) \pm 0.73 . There was a significant difference in this parameter among sampling stations $(\mathrm{F}=59.07042 ; \mathrm{p}=0.0000)$, but this difference was not observed between sexes $(\mathrm{F}=1.352240 ; \mathrm{p}=0.2599)$. In terms of shell size, the Tukey test showed significant differences of the St6, St13, St20 and St21, which presented smaller animals in relation to the other sample stations. Coincidentally, these first stations corresponded to artificial structures (concrete walls) at Canavieiras (St6), Port of Ilhéus (St13 and St21) and Maraú dock (St20). Population samples collected at St14 (Canavieiras), St19 (Porto do Campo, Camamu) and St22 (Barra do Sargi, Uruçuca, Ilhéus), all with intact mangroves and tall trees, presented the highest means in shell height $(\geq 25 \mathrm{~mm})$ (Table 1).

Regarding the sex ratio, of the total of 880 specimens analyzed, 461 were males (M) and 419 females (F), which resulted in a mean $\mathrm{M}: \mathrm{F}$ ratio of 1.21: 1, considering all samples. As is shown by this result and also in relation to the sex ratio in each sample station, there was in general a small predominance of males in relation to females. This ratio was higher than the value 2.0 in some sample stations (St1, St8, St11 and St22) and less than 0.6 in others (St4, St17 and St21) (Table 1).

\subsection{Reproductive apparatus - morphology and morphometry}

In males, it was observed a conspicuous penis (Figure 2A), which was yellow in color and located behind the right eye tentacle. Histological analysis showed muscular constitution of the organ and that it is covered by cylindrical epithelium (Figure 2B). The length of the penis ranged from
1.5 to $9.98 \mathrm{~mm}($ Mean $=5.376, \mathrm{SD} \pm 1.470 \mathrm{~mm}, \mathrm{n}=211)$. The prostate, organ responsible for sperm nutrition and transport, presented a yellow-orange color and was located in the right lateral portion of palial cavity, parallel to the anus and above the columellar muscle (Figure 2A). The spermatic duct was located in the distal portion of prostate in the right lateral region of the head and presented cilia, being darker than the penis and with a base marked by a constriction (Figure 2A). The prostate length varied between 3.67 and $11.68 \mathrm{~mm}$ (Mean $=6.923, \mathrm{SD} \pm 1.555 \mathrm{~mm}$, $\mathrm{n}=211$ ). The distance from the opening of the prostate to the anus ranged from zero to $1.3 \mathrm{~mm}$ (Mean $=0.422$, $\mathrm{SD} \pm 0.261 \mathrm{~mm}, \mathrm{n}=211$ ).

As shown in Table 2, there was a positive correlation between the parameters: penis length versus shell height, prostate length $v s$. shell height and of prostate length $v s$. penile length, and a negative correlation between the distance from prostate to anus $v s$. shell height. Of these, the prostate length $v s$. shell height was significant $(\mathrm{p}<0.05)$.

In females, the gonoduct (palial oviduct) was thin and transparent and located below the surface of epithelium, in the right part of mantle cavity, parallel to the rectum, having cream color, smooth texture, cylindrical shape and a single spiral, with the anus located below this (Figure 3). The gonad was located along with the digestive gland, following a pattern of intercalation of colors, yellow and black, respectively (Figure 3). It was also observed the presence of the bursa copulatrix. The length of palial oviduct ranged from 2.37 to $9.12 \mathrm{~mm}$ (Mean $=5.328$, $\mathrm{SD} \pm 1.329 \mathrm{~mm}, \mathrm{n}=229$ ). The distance between the opening of the anus and vulva ranged from 1.66 to $3.55 \mathrm{~mm}$ (Mean $=2.412, \mathrm{SD} \pm 0.391 \mathrm{~mm}, \mathrm{n}=229)$. In most females of all sampling stations, not shown, eggs were found in the mantle cavity. All correlations between distances were positive (Table 2), being the length of palial oviduct versus shell height was significant $(\mathrm{p}<0.05)$.

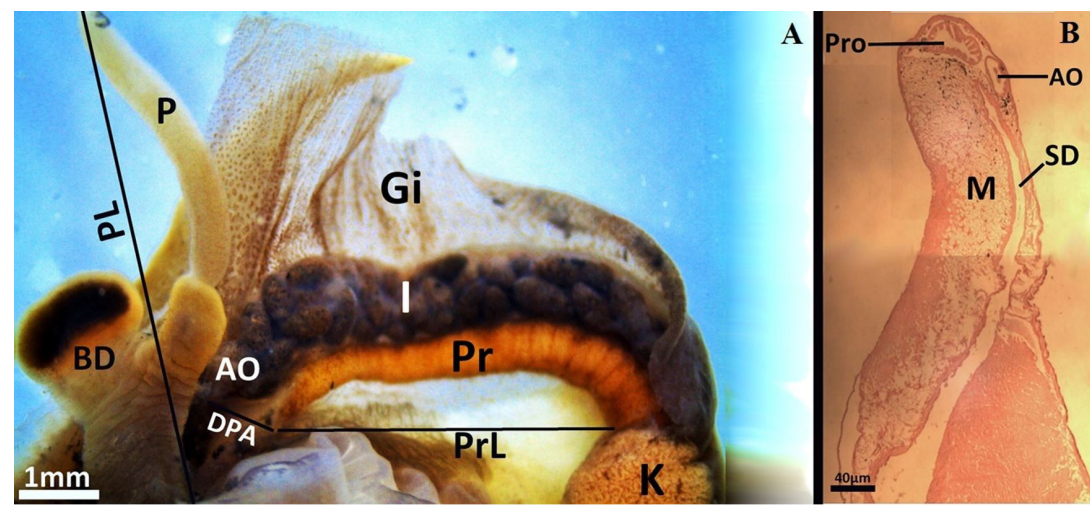

Figure 2. Morphology of Littoraria angulifera, evidencing (A) morphometry and anatomical and (B) histological details (spermatic duct and openings of the prostate and anus) of the male reproductive tract and of other organs, viewed under de stereoscopic and optical microscope, respectively. $\mathrm{AO}=$ Anal Opening; $\mathrm{BD}=$ Basal Disc; $\mathrm{DPA}=$ Distance from Prostate to Anus; $\mathrm{Gi}=$ Gills; $\mathrm{I}=$ Intestine; $\mathrm{K}=$ Kidney; $\mathrm{M}=$ Muscle tissue; $\mathrm{P}=$ Penis; $\mathrm{PL}=$ Penile Length; $\mathrm{Pr}=\operatorname{Prostate}$; PrL = Prostate Length; Pro = Prostate Opening; SD = Spermatic Duct. 
Table 2. Morphometric correlations of Littoraria angulifera reproductive apparatus on the southern coast of Bahia, Brazil. $\mathrm{n}=440$, being 211 males and 229 females.

\begin{tabular}{lc}
\hline \multicolumn{1}{c}{ Parameters } & $\begin{array}{c}\text { Coefficient of determination } \\
\text { (R-squared) }\end{array}$ \\
\hline Penis length $v s$. shell height & $\mathrm{y}=0.2445 \mathrm{x}+19.543 ; \mathrm{R}^{2}=0.0172$ \\
Prostate length $v s$. shell height & $\mathrm{y}=0.8872 \mathrm{x}+14.685 ; \mathrm{R}^{2}=0.2477$ \\
Prostate length $v s$. penile length & $\mathrm{y}=0.1152 \mathrm{x}+4.5774 ; \mathrm{R}^{2}=0.0148$ \\
Distance from prostate to anus $v s$. shell height & $\mathrm{y}=-3.3139 \mathrm{x}+22.237 ; \mathrm{R}^{2}=0.105$ \\
Length of palial oviduct $v s$. shell height & $\mathrm{y}=1.9269 \mathrm{x}+10.518 ; \mathrm{R}^{2}=0.7639$ \\
Distance from anus to vulva $v s$. shell height & $\mathrm{y}=3.566 \mathrm{x}+12.181 ; \mathrm{R}^{2}=0.2332$ \\
Distance from anus to vulva $v s$. palial oviduct length & $\mathrm{y}=1.2417 \mathrm{x}+2.3321 ; \mathrm{R}^{2}=0.1374$ \\
\hline
\end{tabular}

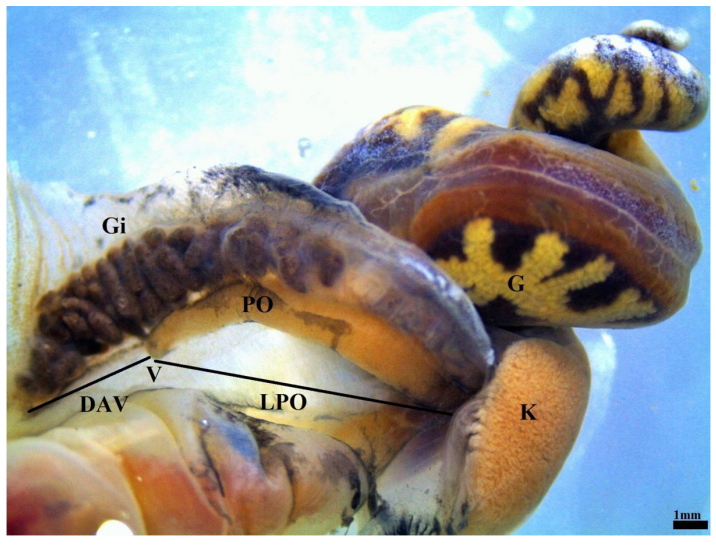

Figura 3. Morphology of Littoraria angulifera, evidencing anatomical/ morphometric details of the female reproductive tract and of other organs under a stereoscopic microscope. $\mathrm{DAV}=$ Distance from Anus to Vulva; $\mathrm{Gi}=\mathrm{Gills} ; \mathrm{G}=\mathrm{Gonad}$; $\mathrm{K}=$ Kidney; $\mathrm{LPO}=$ Length of Palial Oviduct; $\mathrm{PO}=$ Palial Oviduct; $\mathrm{V}=$ Vulva.

\section{Discussion}

Littoraria angulifera is known to have great shape plasticity and in shell coloration. Using material from museum collections and field collections in the eastern and western tropical Atlantic, Merkt and Ellison (1998) tested two hypotheses regarding the phenotypic variation of the shell in this species, the first of the dispersal restriction along the tropical Atlantic due to regime of the main marine currents and the second linked to habitat population characteristics. The absence of genital geographic variation led the authors to reject the hypothesis of dispersion and to believe in the influence of the habitat on the chromatic polymorphism and shell structure. The color polymorphism was also observed in the congeneric species L. pallescens, the mangrove leaf snail, by Cook and Freeman (1986), who observed, through experimental work, that the yellow individuals had less robust shell (thinner and less heavy) compared to dark ones, but less rapid heating compared to dark ones. The authors believe that this may be related to the occupation behavior of the leaf surface in this species. Taking this result a parameter, the predominance of the dark color observed in $L$. angulifera in the present study favors populations of intact mangroves, with greater shading, and disadvantages those that occupy sparse mangroves and artificial substrates. This further explains the small size of individuals in these latter sites and the paler coloration of animals collected on consolidated substrates in areas of nautical activity such as ports, shipyards and berths. The shell thermal characteristics in relation to their color and habitat were also mentioned for $L$. angulifera by Merkt and Ellison (1998).

Based on the premise that physiological stress interferes in the growth of organisms, the desiccation caused by the occupation of artificial substrates and in sparse mangroves was probably the main cause of the smaller size of L. angulifera in these areas. In addition to disturbances in growth, Merkt and Ellison (1998) and Melo et al. (2012) call attention to the fact that there may be an increase in mortality and consequently a decrease in population density of these places. Tanaka and Maia (2006) studied the morphological variation of $L$. angulifera among Brazilian northeast mangroves and although they found a great phenotypic variation in small and large spatial scales, verified that specimens from mangrove with small trees were more resistant in desiccation tests in relation to those of mangroves more intact and with higher vegetation. This suggests physiological adaptation to less favorable environments, although with damage to growth and possibly in other aspects of their development, such as reproduction.

In addition to desiccation, pollution seems to also interfere in the growth of this and congeneric species. The results obtained by Costa et al. (2013) in a study in southeastern Brazil, using L. angulifera as an organotin bioindicador showed that animals from polluted areas near to port of Vitória (Espírito Santo) were smaller than those sampled in mangroves well preserved. In a study with L. scabra in Tanzania, De Wolf and Rashid (2008) found that individuals with high levels of heavy metals were significantly smaller and lighter compared to those of unpolluted mangroves. These results suggest that when both are present, there may be a synergistic effect of desiccation and pollution, with interference on the growth of Littoraria species.

The predominance of males in some sample stations and of females in others may have been slightly influenced by the sampling methodology used in this study, but 
overall there was a balance around the ratio $1: 1$. Empirical observations lead to indications that females occupy lower strata than males. This had already been demonstrated experimentally for L. angulifera by Lenderking (1954) however more studies may provide more reliable evidences about this aspect.

The study showed broad compliance in reproductive apparatus with the previous descriptions made by Marcus and Marcus (1963), Merkt and Ellison (1998) and Reid (1999) for the species. Merkt and Ellison (1998) have shown that anfiatlantic populations show uniformity in genital morphology, concluding that it is a unique species throughout this region. According to Reid (1999), the male reproductive apparatus of the genus Littoraria resembles that of the genus Littorina, described by Linke (1933) and Fretter and Graham (1994). In relation to the reproductive apparatus of the females, unlike the one observed in the ovigerous congeneric species of L. angulifera, in which the palial oviduct has four to six turns and with several glands responsible for the encapsulation of the eggs (Reid, 1999), in relation to the descriptions of Marcus and Marcus (1963) and Reid (1999), this study corroborated that L. angulifera has only one simple turn, which according to these, does not present encapsulation glands, thus resembling species of the subgenus Littorinopsis and clearly reflecting the ovoviviparity of the species.

In relation to the use of the morphometric parameters (prostate length and distance between the opening of the prostate to the anus in males; oviduct length and distance between the vulva to the anus in females), although until the present study, this morphometry has not been used for L. angulifera, morphophysiological changes in the reproductive system, to the detriment of organotin contamination, were observed in Europe by Bauer et al. (1995) in Littorina littorea (L.), an oviparous species, which reported a gradual replacement of the oviduct by a prostate, and in the latter stage there may be the development of a penis and a seminal sulcus, with sterilization of the female called intersex. Zeidan et al. (2018) confirmed that morphometric changes occurred in the gonads of $L$. angulifera females submitted to injections and feed contaminated with tributyltin, which presented palial oviduct more elongated than the negative control, indicating masculinization and possibly impairment of larval release to the environment.

A significant positive correlation between oviduct length and shell height was also observed in the study. This assumes fertility increase in larger animals, converging with the interpretation of Merkt and Ellison (1998) that larger females may have larger litters, since they have more space to store and to hatch the eggs in the mantle cavity. Thus, this parameter can be used in reproductive evaluation of this species.

In conclusion, this study confirmed: (a) the previous descriptions of the reproductive apparatus of $L$. angulifera, including that it is an ovoviviparous animal; (b) a positive correlation between the size of the oviduct and prostate in relation to the shell height; (c) the occurrence of smaller animals in environments with greater exposure to solar radiation and human occupation, where the shells were also more brittle. This last result reinforces the use of this species as bioindicator using this parameter. However, to reinforce the adequacy of $L$. angulifera use in estuarine monitoring, the effect of pollutants also needs to be investigated.

\section{Acknowledgements}

The authors are grateful to Susana Galante and Ana Hilário (LEME / UE, Portugal), for assistance in histotechnical processing; to Dr. Carlos Miguez Barroso (LEME / UE) for their suggestions; Dr. David G. Reid (London Natural History Museum) for his contribution to the interpretation of species biology and the availability of bibliographic material; FAPESB (Bahia, Brazil), for study funding through the project TSC 0010/2011; FAPESB and CAPES (Brazil) for the grant of doctoral scholarship to the first author.

\section{References}

BAUER, B., FIORONI, P., IDE, I., LIEBE, S., OEHLMANN, J., STROBEN, E. and WATERMANN, B.T., 1995. TBT effects on the female genital system of Littorina littorea: a possible indicator of tributyltin pollution. Hydrobiologia, vol. 309, no. 1, pp. 15-27. http://dx.doi.org/10.1007/BF00014468.

COOK, L.M. and FREEMAN, P.M., 1986. Heating properties of morphs of the mangrove snail Littoraria pallescens. Biological Journal of the Linean Society, vol. 29, no. 1, pp. 295-300. http:// dx.doi.org/10.1111/j.1095-8312.1986.tb00281.x.

COSTA, M.B.; ZAMPROGNO, G.C.; PEDRUZZI, F.C.; DALBEM, G.B. and TOGNELLA, M.M.P. 2013. Assessing the continuous impact of Tributyltin from Antifouling Paints in a Brazilian mangrove area using Intersex in Littoraria angulifera (Lamarck, 1822) as Biomarker. International Journal of Oceanography, vol. 2013, no. 1, pp. 1-8. http://dx.doi.org/10.1155/2013/769415

DE WOLF, H. and RASHID, R., 2008. Heavy metal accumulation in Littoraria scabra along polluted and pristine mangrove areas of Tanzania. Environmental Pollution, vol. 152, no. 3, pp. 636-643. http://dx.doi.org/10.1016/j.envpol.2007.06.064. PMid:17716792.

BRASIL. MARINHA DO BRASIL. DIRETORIA DE HIDROGRAFIA E NAVEGAÇÃO - DHN, 2014 [viewed January 3, 2014] Tábuas de marés de 2014 [online]. Available from: http://www. mar.mil.br/dhn/chm/box-previsao-mare/tabuas/

FRETTER, V. and GRAHAM, A., 1994. British prosobranch molluscs: Their functional anatomy and ecology. London: The Ray Society, vol. 161.

GUTIERREZ, P.C., 1988. The ecology and behavior of the mangrove periwinkle, Littoraria angulifera. Biotropica, vol. 20, no. 4, pp. 352-356. http://dx.doi.org/10.2307/2388333.

KOHLMEYER, J. and BEBOUT, B., 1986. On the occurrence of marine fungi in the diet of Littorina angulifera and observations on the behavior of the periwinkle. Marine Ecology, vol. 7, no. 1, pp. 333-343. http://dx.doi.org/10.1111/j.1439-0485.1986.tb00168.x.

LENDERKING, R.E., 1954. Some recent observations on the biology of Littorina angulifera Lam. of Biscayne and Virginia Keys, 
Florida. Bulletin of Marine Science of the Gulf and Caribbean, vol. 3, no. 1, pp. 273-295.

LINKE, O., 1933. Morphologie and Physiologie des Genitalapparatus der Nordseelittorinen. Helgoländer Wissenschaftliche Meeresuntersuchungen, vol. 19, no. 1, pp. 1-60.

MACNAE, W., 1969. A General account of the fauna and flora of mangrove swamps and forests in the Indo-West-Pacific region. Advances in Marine Biology, vol. 6, no. 1, pp. 73-270. http:// dx.doi.org/10.1016/S0065-2881(08)60438-1.

MARCUS, E. and MARCUS, E., 1963. Mesogastropoden von der Küste São Paulos. Akademie der Wissenschaften: Abhandlungen der math.-naturw. Klasse, vol. 1, no. 1, pp. 1-105.

MARTÍNEZ, S., MAHIQUES, M.M. and BURONE, L., 2013. Mollusks as indicators of historical changes in an estuarine-lagoonal system (Cananéia-Iguape, SE, Brazil). The Holocene, vol. 23, no. 1, pp. 888-897. http://dx.doi.org/10.1177/0959683612470175.

MATTHEWS-CASCON, H. and LOTUFO, T.M.C., 2006. Biota marinha da costa oeste do Ceará. Brasília: MMA, vol. 24, 248 p. Série Biodiversidade, no. 1.

MCCARTY, L.S. and MUNKITTRICK, K.R., 1996. Environmental biomarkers in aquatic toxicology: fiction, fantasy, or functional? Human and Ecological Risk Assessment, vol. 2, no. 2, pp. 268274. http://dx.doi.org/10.1080/10807039609383607.

MELO, C.G.B., MAIA, R.C. and ROCHA-BARREIRA, C.A., 2012. Shell morphology variation and population density of Littoraria angulifera (Mollusca: Gastropoda) in mangrove forests of Ceará State, Brazil. Arquivo de Ciências Marinhas, vol. 45 , no. 1 , pp. $68-76$.

MERKT, R.E. and ELLISON, A.M., 1998. Geographic and habitatspecific morphological variation of Littoraria (Littorinopsis) angulifera (Lamarck, 1822). Malacologia, vol. 40, no. 1-2, pp. 279-295.

PLAZIAT, J.C., 1984. Mollusk distribution in the mangal. In: F.D. POR and I. DOR, eds. Hydrobiology of the Mangal. The Ecossystem of the Mangrove Forests. The Hague: Dr. W. Junk Publishers, pp. 111-143.
REID, D.G., 1986. The Littorinid Molluscs of Mangrove Forests in the Indo-Pacific Region. London: British Museum. Natural History.

REID, D.G., 1989. The comparative morphology, phylogeny, and evolution of the gastropod family Littorinidae. Philosofical Transactions of the Royal Society B, vol. 26, no. 1, pp. 39-68. http://dx.doi.org/10.1098/rstb.1989.0040.

REID, D.G., 1999. The genus Littoraria Griffith \& Pidgeon, 1834 (Gastropoda: Littorinidae) in the tropical eastern Pacific. The Veliger, vol. 42, no. 1, pp. 21-53.

SCHAEFFER-NOVELLI, Y., CINTRÓN-MOLERO, G., ADAIME, R.R. and CAMARGO, T.M., 1990. Variability of mangrove ecosystems along the Brazilian coast. Estuaries, vol. 13, no. 2, pp. 204-218. http://dx.doi.org/10.2307/1351590.

SCHIAVETTI, A., SCHILLING, A.C. and OLIVEIRA, H.T. 2002. Caracterização sócio-ambiental da Bacia Hidrográfica do Rio Cachoeira, Sul da Bahia, Brasil. In: A. Schiavetti and A.F.M. Camargo, eds. Conceitos de Bacias Hidrográficas: teoria e aplicações. Ilhéus: Editus. p. 289.

TANAKA, M.O. and MAIA, R.C., 2006. Shell morphological variation of Littoraria angulifera among and within mangroves in NE Brazil. Hydrobiologia, vol. 559, no. 1, pp. 193-202. http:// dx.doi.org/10.1007/s10750-005-1449-x.

VERMEIJ, G.J., 1973. Molluscs in mangrove swamps: physiognomy, diversity and regional differences. Systematic Zoology, vol. 22, no. 4, pp. 609-624. http://dx.doi.org/10.2307/2412965.

ZEIDAN, G.C. and BOEHS, G., 2017. Assessment of tributyltin contamination based on imposex in Stramonita rustica (Mollusca: Gastropoda) along southern Bahia coast, northeastern Brazil. Brazilian Journal of Biology $=$ Revista Brasileira de Biologia, vol. 77, no. 1, pp. 185-190. http://dx.doi.org/10.1590/15196984.15115. PMid:27533729.

ZEIDAN, G.C., BARROSO, C.M. and BOEHS, G., 2018. Efficiency of anesthetics on female gastropod Littoraria angulifera. Boletim do Instituto de Pesca, vol. 44, no. 3, pp. e304. http:// dx.doi.org/10.20950/1678-2305.2018.304. 